\title{
PENGARUH EDUKASI KONSELOR LAKTASI TERHADAP PARTISIPASI IBU MELAKUKAN INISIASI MENYUSUI DINI
}

\author{
Indah Yun Diniaty Rosidi ${ }^{1}$, Arisna Kadir ${ }^{2}$ \\ ${ }^{1}$ STIKES Nani Hasanuddin Makassar \\ ${ }^{2}$ STIKES Nani Hasanuddin Makassar
}

Alamat korespondensi : (indah@stikesnh.ac.id /082347708379)

\begin{abstract}
ABSTRAK
Inisiasi Menyusu Dini (IMD) merupakan faktor yang terpenting sebagai penentukeberhasilan ASI eksklusif, sebab produksi ASI akan terstimulasi sejak dini. Tujuan penelitian ini adalah untuk mengetahui pengaruh edukasi konselor laktasi terhadap partisipasi ibu melakukan IMD di Puskesmas Jumpandang Baru Kota Makassar. Penelitian ini merupa jenis penelitian quasi experiment dengan desain post-test only, non-equivalent control group design. Pengambilan sampel dilakukan dengan teknik purposive sampling dan sampel sebanyak 60 responden. Instrumen yang digunakan adalah lembar kuesioner dan daftar checklist. Data dianalisis menggunakan program SPSS dengan uji statistik chi-square. Berdasarkan hasil analisis hubungan karakteristik responden dengan partisipasi ibu diperoleh nilai $\rho=0,223$ pada umur; $\rho=0,101$ pada pendidikan; $\rho=0,322$ pada pekerjaan dan $\rho$ $=1,000$ pada gravida berarti tidak ada hubungan bermakna antara karakteristik responden terhadap partisipasi ibu dalam melakukan IMD. Sedangkan pengaruh edukasi konselor laktasi dengan partisipasi ibu diperoleh nilai $\rho=0,014$ berari ada pengaruh yang signifikan antara edukasi konselor laktasi terhadap partisipasi ibu dalam melakukan IMD. Kesimpulan dalam penelitian ini adalah edukasi laktasi yang diberikan konselor sebanyak $4 x$ saat prenatal secara berkesinambungan berpengaruh terhadap tingginya partisipasi ibu dalam melakukan IMD. Diharapkan adanya penelitian lebih lanjut dan dikembangkan secara lebih mendalam terutama variabel sosial budaya masyarakat, dukungan keluarga, serta pelatihan bidan terhadap pelaksanaan IMD.
\end{abstract}

Kata Kunci: IMD, partisipasi, edukasi, konselor, laktasi

\section{PENDAHULUAN}

Air Susu Ibu (ASI) adalah cairan hasil sekreksi kelenjar payudara ibu dan merupakan makanan yang paling penting terutama dalam bulan-bulan awal kehidupan. Air Susu lbu Eksklusif (ASI Eksklusif) adalah ASI yang diberikan kepada bayi sejak lahir hingga usia bayi 6 (enam) bulan, tanpa menambahkan dan/atau mengganti dengan makanan atau minuman lain (Peraturan Pemerintah Republik Indonesia No.33, 2012; Sukarni, 2013).

Nutrisi yangbaik pada bayi mempercepat pertumbuhan dan perkembangan yang optimal. Menyusui merupakan kesempatan untuk berinteraksi sosial, fisiologis, dan bahkan edukasi antara orang tuadan bayi. Menyusui juga dapat membangun dasaruntuk mengembangkan kebiasaan makan yangbaik yang berlansung seumur hidup (Lowdermilket.al, 2013).

Kemajuan suatu bangsa dimulai dari sumber daya manusia yang berkualitas, untuk menciptakannya harus dimulai sejak dini atau bayi. Salah satu cara yang dapat dilakukan dalam hal ini adalah pemberian ASI pada satu jam pertama kelahiran atau sering disebut dengan Inisiasi Menyusu Dini (IMD). Pelaksanaan IMD merupakan awal keberhasilan dalam pemberian ASI ekslusif, dapat mencegah atau menurunkan angka kematian bayi dan juga dipercaya dapat membantu meningkatkan daya tahan tubuh terhadap penyakit yang beresiko kematian tinggi seperti kanker syaraf, leukimia, dan berdampak psikologis ibu dan bayi (Roesli, 2008).

IMD merupakanproses alami mengembalikan bayi manusia untuk menyusu yaitu dengan memberikan kesempatanpada bayi untuk mencari dan menghisap ASI sendiri dalam satu jam pertama pada awal kehidupannya (Roesli, 2008). Edukasi orangtua, dukungan dari pasangan dan keluarga merupakan faktor penentu utama dalampengambilan keputusan ibu untuk menyusui (Lowdermilk et.al, 2013). IMD merupakan faktor yang terpenting sebagai penentu keberhasilan ASI eksklusif. Karena dengan IMD, produksi ASI akan terstimulasi sejak dini. IMDjuga mempercepat pengeluaran placenta, dan mempercepat pengeluaran ASI (Tamara, 2011).

WHO-UNICEF mengeluarkan protokol tentang "ASI Segera" yang harus diketahui tenaga kesehatan. Protokol tersebut adalah melakukan kontak kulit ibu dengan kulit 
bayisegera setelah lahir selama paling sedikit satujam dan bantu ibu mengenali kapan bayinya siap menyusu. Kontak langsung kulit ibu dan bayi akan memberikan kehangatan dan ikatan antara ibu dan bayi (Majid, 2008).

Kegagalan IMD disebabkan oleh beberapa faktor antara lain kurangnya pengetahuan ibu mengenai pentingnya IMD, sikap ibu yang menolak pelaksanaan IMD, kurangnya dukungan keluarga dan tenaga kesehatan, kurang tersedianya sarana kesehatan yang memadai, dan kebijakan pemerintah yang kurang mendukung pelaksanaan IMD yang menyebabkan ibu kurang percaya diri untuk melakukan IMD dan bayi akan kehilangan sumber makanan ang vital (Virarisca, 2010).

Kurangnya pemahaman tentang IMD dan pemberian ASI secara ekslusif, sehingga pelaksanaan IMD dan pemberian ASI ekslusif tidak dihiraukan (Febrianty, 2011). Pemahaman tentang IMD dan pemberian ASI secara ekslusif merupakan persoalan yang sangat penting. Yang memungkinkan terlaksananya IMD dan pemberian ASI secara ekslusif, apabila individu, keluarga, petugas kesehatan serta masyarakat sudah memahami tentang pengertian, manfaat, serta tujuan dari IMD dan pemberian ASI ekslusif (Roesli, 2008).

Berkaitan dengan hal tersebut pengetahuan dan pemahaman akan pentingnya IMD pada bayi baru lahir menjadi suatu kebutuhan bagi semua petugas kesehatan dan masyarakat luas terutama ibu yang sedang hamil, demikian juga persepsi dan pendapat masyarakat yang salah tentang IMD juga menjadi penghambat suksesnya program pemerintah ini, sehingga informasi yang benar tentang program IMD hendaknya terus disosialisasikan pada masyarakat luas sehingga apa yang menjadi tujuan program pemerintah ini dapat tercapai dengan baik. Peneliti tertarik untuk melakukan penelitian tentang IMD dengan judul pengaruh edukasi konselor laktasi terhadap partisipasi ibu dalam melakukanIMD di Puskesmas Jumpandang Baru 2018.

\section{BAHAN DAN METODE}

Lokasi, Populasi, Sampel

Penelitian ini dilaksanakan di

Puskesmas Jumpandang Baru pada bulan februari sampai mei 2018. Jenis penelitian ini adalah quasi experiment dengan desain posttest only, non-equivalent control group design. Populasi dalam penelitian ini adalah seluruh ibu hamil trimester III yang datang di Puskesmas Jumpandang Baru pada bulan Januari-Februari 2018 sebanyak 102 orang dengan sampel sebanyak 60 orang.

1. Kriteria inklusi
a. Ibu hamil trimester III
b. Rencana persalinan ditolong oleh tenaga kesehatan
c. Bersedia menjadi responden

2. Kriteria eksklusi
a. Ibu atau persalinan

\section{Pengumpulan Data}

1. Data primer adalah data yang diperoleh dari observasi dan wawancaralangsung dengan ibu tentang umur, pendidikan, pekerjaan, kehamilan,status tempat tinggal dan IMD.

2. Data sekunder adalah data yang diperoleh dari Puskesmas, DinasKesehatan setempat.

\section{Pengolahan Data}

1. Editing yaitu melakukan pengecekan terhadap hasil pengisian kartu kuesioner kelengkapan identitasdan hasil yang di berikan oleh responden.

2. Coding yaitu memberikan kode berupa angka-angka untuk setiap hasilpada daftar checklist.

3. Transfering yaitu data yang telah di beri kode disusun secara berurutan mulai dari responden pertama hingga responden yang terakhiruntuk dimasukkan kedalam tabel.

4. Tabulating yaitu data yang telah diolah kemudian disusun dalam bentuktabel distribusi frekuensi.

\section{Analisis Data}

1. Analisis Univariat

Digunakan untuk mendeskripsikan variabel penelitian guna memperoleh gambaran atau karakteristik sebelum dilakukan analisi bivariat. Hasil dari penelitian ditampilkan dalam bentuk distribusi frekuensi.

2. Analisis Bivariat

Analisis bivariat yang dilakukan adalah tabulasi silang antara dua variabel yaitu variabel independen dan dependen. Analisis bivariat yang digunakan untuk mengetahui hubungan terhadap objek penelitian adalah menggunakan uji chi square. 
HASIL PENELITIAN

1. Analisis Univariat

Tabel 1 Distribusi karakteristik responden

\begin{tabular}{|c|c|c|c|c|c|}
\hline \multirow{3}{*}{ Karakteristik } & \multicolumn{4}{|c|}{ Kelompok } & \multirow{3}{*}{ value } \\
\hline & \multicolumn{2}{|c|}{ Kontrol } & \multicolumn{2}{|c|}{ Intervensi } & \\
\hline & $\mathrm{n}$ & $\%$ & $\mathrm{n}$ & $\%$ & \\
\hline \multicolumn{6}{|l|}{ Umur } \\
\hline Tidak & 21 & & 25 & & \multirow{4}{*}{0,223} \\
\hline Berisiko & 21 & 10 & 25 & 83,5 & \\
\hline Risiko & 9 & 30 & 5 & 16,7 & \\
\hline Total & 30 & 100 & 30 & 100 & \\
\hline \multicolumn{6}{|l|}{ Pendidikan } \\
\hline Tinggi & 20 & 66,7 & 20 & 66,7 & \multirow{3}{*}{$0,101^{\mathrm{a}}$} \\
\hline Rendal & 10 & 33,3 & 10 & 33,3 & \\
\hline Total & 30 & 100 & 30 & 100 & \\
\hline \multicolumn{6}{|l|}{ Pekerjaan } \\
\hline Bekerja & 13 & 43,3 & 9 & 30 & \multirow{3}{*}{$0,322^{b}$} \\
\hline Tidak Bekerja & 17 & 56,7 & 21 & 70 & \\
\hline Total & 30 & 100 & 30 & 100 & \\
\hline \multicolumn{6}{|l|}{ Gravida } \\
\hline Primigravida & 22 & 73,3 & 25 & 83,3 & \multirow{3}{*}{$1,000^{\circ}$} \\
\hline Multigr & 8 & 26,7 & 5 & 16,7 & \\
\hline Total & 30 & 100 & 30 & 100 & \\
\hline
\end{tabular}

Berdasarkan tabel diatas, hasil uji statistik juga menunjukkan pada semua karakteristik bahwa tidak ada hubungan bermakna antara umur, pendidikan, pekerjaandan gravida terhadap partisipasi ibu dalam melakukan IMD disetiap kelompok $(\rho>0,05)$ yang berarti bahwa hasil dari penelitian dan intervensi yang diberikan bukan pengaruh dari karakteristik sampel penelitian.

\section{Analisis Bivariat}

Tabel 2 Pengaruh antara Edukasi Konselor Laktasi dengan Partisipasi lbu Melakukan IMD di Puskesmas Jumpandang Baru 2018

\begin{tabular}{|l|c|c|c|c|c|c|}
\hline \multirow{2}{*}{ Edukasi } & \multicolumn{3}{|c|}{$\begin{array}{c}\text { Partisipasi Ibu } \\
\text { dalam IMD }\end{array}$} & \multicolumn{2}{c|}{ Total } \\
\cline { 2 - 6 } & Tinggi & Rendah & \multicolumn{2}{c|}{} \\
\cline { 2 - 6 } & $\mathrm{n}$ & $\%$ & $\mathrm{n}$ & $\%$ & $\mathrm{n}$ & $\%$ \\
\hline $\begin{array}{l}\text { Diberikan } \\
\text { oleh BIdan }\end{array}$ & 15 & 50 & 15 & 50 & 30 & 100 \\
\hline $\begin{array}{l}\text { Diberikan } \\
\text { oleh konselor } \\
\text { laktasi }\end{array}$ & 25 & 83,3 & 5 & 16,7 & 30 & 100 \\
\hline Total & 40 & 66,7 & 20 & 33,3 & 60 & 100 \\
\hline \multicolumn{1}{|c|}{0 value } & \multicolumn{6}{|c|}{0,014} \\
\hline
\end{tabular}

\section{Berdasarkan tabel diatas} menunjukkan bahwa pada kelompok kontrol (edukasi diberikan oleh bidan) memiliki jumlah yang sama yaitu masingmasing terdapat 15 responden (50\%) dengan partisipasi dalam melakukan IMD dikategorikan tinggi dan rendah. Sedangkan pada kelompok intervensi (edukasi diberikan oleh konslor laktasi) terdapat 25 responden $(83,3 \%)$ partisipasi tinggi dalam melakukan IMD dan 5 responden (16,7\%) merupakan partisipasi rendah dalam melakukan IMD.

Dari hasil analisa dengan uji statistik chi-square diperoleh $\rho=0,014<\alpha 0,05$ maka dapat disimpulkan bahwa ada pengaruh edukasi konselor laktasi terhadadap partisipasi dalam melakukan IMD.

\section{PEMBAHASAN}

1. Karakteristik Responden

Penelitian ini menemukan bahwa semua karakteristik responden tidak memiliki hubungan bermakna antara umur, pendidikan, pekerjaan dan gravida terhadap partisipasi ibu dalam melakukan IMD, yang berarti tidak ada pengaruh yang signifikan antara karakteristik ibu hamil terhadap partisipasi ibu melakukan IMD.

Umur merupakan variabel yang digunakan sebagai ukuran mutlak indikator fisiologis dengan kata lain pengunaan fasilitas pelayanan kesehatan akan berhubungan dengan umur, dimana yang semakin tua mempunyi karakteristik fisiologis dengan tanggung jawab sendiri (Notoatmodjo, 2003).

lbu yang berumur 20-35 tahun merupakan ibu yang tidak beresiko dan ibu dengan umur $<20$ tahun dan $\geq 35$ tahun merupakan ibu dengan beresiko. Dari penelitian ini menggambarkan baik ibu dengan umur yang muda maupun tua tidak mempengaruhi keberhasilan menyusui, hal ini disebabkan oleh kemauan dan pengetahuan yang dimiliki oleh ibu untuk melakukan IMD dan memberikan ASI kepada bayinya. Hal ini sejalan dengan penelitian di Magelang yang menyatakan bahwa ada hubungan yang bemakna antara umur dengan pelaksanaan IMD (Hastuti, 2010).

Dari hasil penelitian Hastuti (2010) tentang hubungan pengetahuan, pendidikan dan pekerjaan ibu dengan pemberian makanan pendamping ASI ( MP - ASI ) pada bayi di puskesmas bahu kecamatan malalayang kota manado. Dari penelitian menunjukkan bahwa tidak ada hubungan yang signifikan antara pendidikan dan pekerjaan ibu dalam pemberian MP-ASI pada bayi.

Pendidikan adalah kegiatan atau proses belajar yang terjadi dimana saja, kapan saja, dan oleh siapa saja.Seseorang dapat dikatakan belajar apa bila didalam dirinya terjadi perubahan dari tidak tahu 
menjadi tahu, dari tidak mengerjakan menjadi dapat mengerjakan sesuatu. Berdasarkan pengertian tersebut dapat diartikan bahwa pendidikan tidak hanya didapatkan di bangku sekolah sebagai pendidikan formal akan tetapi dapat diperoleh kapan dan dimana saja. Hai ini dibuktikan dari hasil penelitian ini, yang menunjukkan bahwa jumlah pada kelompok yang berpendidikan rendah dibandingkan dengan tingkat pendidikan tinggi hampir tidak jauh berbeda. Pendidikan dapat mempengaruhi tingkat pengetahuan seseorang, semakin tinggi tingkat pendidikan seseorang makin mudah menerima informasi, sehingga makin baik pengetahuannya, akan tetapi seseorang yang berpendidikan rendah belum tentu berpengetahuan rendah. Pengetahuan tidak hanya diperoleh dari pendidikan formal akan tetapi juga bias diperoleh melalui pendidikan non formal, seperti pengalaman pribadi, media, lingkungan dan penyuluhan kesehatan, sehingga bisa juga seseorang dengan pendidikan tinggi dapat terpapar denganpenyakit begitu pula sebaliknya (Notoatmodjo, 2010).

Suatu perbuatan yang didasari oleh pengetahuan akan lebih langgeng daripada perbuatan yang tidak didasari oleh pengetahuan, dan orang yang mengadopsi perbuatan dalam diri tersebut akan terjadi proses kesadaran dimana orang tersebut menyadari dalam arti mengetahui terlebih dahulu obyek (stimulus) yaitu hal-hal tentang IMD merasa tertarik terhadap stimulus, menimbang-nimbang baik dan tidaknya pengetahuan mengenai pentingnya IMD terhadap bayi dan dirinya, trial dimana subjek mulai melakukan sesuatu sesuai dengan hal-hal yang diketahuinya untuk menyusui bayinya, adopsi dimana subjek telah berperilaku sesuai dengan pengetahuan yang telah didapatkan (Notoatmodjo, 2007; Febrianty, 2011; Bohari, 2011).

Menurut peneliti pekerjaan adalah mata pencaharian sehari-hari dari seseorang untuk mencari uang dalam memenuhi kebutuhan sehari-hari. Pekerjaan tidak terlaluberperan terhadap seseorang melakukan tindakan IMD kepada bayinya.

Ibu yang mengalami kehamilan pertama dan ibu yang hamil keduakali dan seterusnya, tidak mempengaruhi pelaksanaan IMD. Hal ini disebabkan karena kurangnya pengetahuan dan motivasi ibu. Konseling yang diberikan selama kehamilan tidak dapat meningkatkan pengetahuan, dan perubahan sikap serta praktik IMD. Ibu lebih banyak belajar dari pengalaman anak sebelumnya, pengalaman orang tua dan masyarakat sebagai acuan dalam praktik pemberian ASI pada anak yang dikandung pada saat penelitian (Fikawati dkk., 2009). World Health Organization yang dikutip Notoatmodjo (2003) menyatakan bahwa seseorang memperoleh pengetahuan berasal dari pengalaman sendiri atau pengalaman seseorang. Selain itu kurangnya dukungan keluarga, petugas kesehatan menyebabkan ibu memutuskan untuk memberikan susu formula, buah dan bubur susu (Hector et al., 2005). Faktor yang berpengaruh terhadap pelaksanaan Inisiasi Menyusu Dini (IMD) dan pemberian ASI Eksklusif terutama faktor sikap, motivasi, maupun pengetahuan, baik sikap, motivasi, dan pengetahuan ibu, maupun petugas kesehatan (Alice et al., 2013).

2. ubungan edukasi konselor laktasi dengan partisipasi ibu dalam melakukan IMD

Dalam penelitian ini ada hubungan edukasi konselor laktasi dengan partisipasi ibu dalam melakukan IMD. Hal ini sejalan dengan penelitian yang dilakukan oleh Ramlah, dkk (2014) bahwa terdapat pengaruh edukasi yang diberikan dalam meningkatkan pengetahuan ibu hamil tentang IMD terhadap sikap ibu hamil.

Edukasi adalah suatu proses perubahan perilaku secara terencana pada diri individu, kelompok, masyarakat untuk dapat lebih mandiri dalam mencapai tujuan hidup sehat. Edukasi merupakan proses belajar dari tidak tahu tentang nilai kesehatan menjadi tahu dan dari tidak mampu mengatasi kesehatan sendiri menjadi mandiri (Suliha, 2002; Setiawati, 2008; Ramlah, et al., 2014).

Berdasarkan hasil penelitian ini dapat diketahui bahwa edukasiyang diberikan oleh konselor laktasi dilakukan secara terencana dan terstruktur yaitu sebanyak $4 x$ dengan materi yang berkesinambungan, dengan hasil sebanyak 25 responden $(88,3 \%)$ melakukan IMD dengan pastispasi tinggi yaitu ibu memeluk bayinya, melakukan kontak visual, membelai bayinya, ibu tidak mendorong bayinya dan membiarkan bayinya mencari putting susu ibu.

Hal ini disebabkan proses edukasi yang berjalan efektif, konselor laktasi melibatkan ibu selama proses edukasi berlangsung sehingga ibu aktif mengemukakan permasalahan dan ketidaktahuan ibu tentang IMD, ASI 
Eksklusif, ASI dan menyusui (Anthony, 2010; Aidam, et al,. 2005; Imbar, 2002; Nurafifah, 2007).

Kerjasama dan komunikasi yang baik antara konselor dan ibu serta kemampuan konselor yang menunjukkan sikap terbuka dan bersedia menjadi pendengar yang baik serta menciptakan suasana yang nyaman akan dapat menggali sejauhmana pengetahuan ibu dan mengembangkan pengetahuan ibu tersebut menjadi lebih baik. Faktor lain yang menjadi keberhasilan dalam proses edukasi adalah konselor mampu menumbuhkan kepercayaan dan motivasi ibu, sehingga ibu bisa menerima konselor sebagai sumber informasi yang berdampak terhadap keberanian ibu dalam mengungkapkan ketidaktahuan yang dihadapi sebelumnya. Untuk mempermudah pemahaman ibu terhadap materi pembelajaran yang diberikan oleh konselor maka materi yang disampaikan sesuai masalah yang dihadapi ibu namun tidak keluar dari materi yang dibahas secara terstruktur (Haaron, et al., 2013; Lesmana, 2008; Lumongga, 2011; Depkes, 2007).

Masalah yang disampaikan berdasarkan pengalaman ibu pada anak sebelumnya, dimana masalah itu menjadi informasi selanjutnya oleh konselor dipadukan dengan pendapat para ahli dan beberapa hasil penelitian yang dirangkum dan disampaikan dengan bahasa yang mudah dipahami. Selain itu konselor juga mengajak ibu berpikir tentang sebab dan akibat dari permasalahan tersebut, sehingga informasi lebih mudah dan lama diingat oleh ibu. Menurut Azwar (2003), untuk menjamin keberhasilan pelayanan edukasi perlu konselor yang baik, sehingga dapat menimbulkan kepercayaan dan keterbukaan klien kepada konselor (Haaron, et al., 2013; Lesmana, 2008; Lumongga, 2011; Depkes, 2007).

Intensitas edukasi juga merupakan salah satu yang mempengaruhi peningkatan pengetahuan dan sikap ibu, sehingga semakin sering terjadi kontak antara ibu dan konselor maka semakin sering ibu mendapatkan informasi yang secara tidak langsung meningkatkan pengetahuan dan sikap ibu. Manfaat lain dari intensitas edukasi yang sering adalah adaya pengulangan informasi yang menjadi faktor pendukung dalam pemahaman ibu terhadap informasi tersebut. Informasi atau pengetahuan yang sering dan berulang-ulang dapat meningkatkan retensi pengetahuan seseorang. Waktu yang digunakan untuk edukasi disesuaikan dengan waktu pemeriksaan atau kujungan ibu hamil (Notoatmodjo, 2003; Haaron, et al., 2013; Lesmana, 2008; Lumongga, 2011; Azwar, 2003).

Ibu dengan partisipasi rendah yaitu ibu yang tidak memeluk bayinya, tidak melakukan kontak visual, ibu mendorong bayinya ke putting susu, dan tidak melakukan komunikasi dengan bayinya sebanyak 5 responden (16,7\%).

Mayoritas perilakukurang partisipatif pada partisipasi ibu dalamberkomunikasi dengan bayi Perilaku kurangpartisipatif ibu tidak melakukan komunikasidengan bayi karena ibu beranggapan bahwa bayi belum bisa diajak komunikasi. Komunikasidengan bayi dapat mempererat kasih sayang danrasa aman bagi bayi dan ibu. Komunikasi akanmeningkatkan hubungan batin bayi dan ibu, padapelasanaan IMD ini bayi akan mengalamipenurunan stress hormonal dan diyakini dapatmengurangi kejadian depresi saat melahirkan(Hidayat, 2012).

Responden yang memutus bayi untukmenyusu karena ibu beranggapan bahwa apabilabayi sudah menyusu adalah sudah melakukanIMD. Rangsangan hisapan bayi untuk menyusuakan meningkatkan produksi ASI (Maritalia, 2012). Sebagian masyarakat menganggapbahwa 1 jam pertama ASI belum keluar dan IMDdilakukan pada saat ASI sudah keluar. Sebagianmasyarakat juga beranggapan bahwa ASI yangpertama dapat membahayakan bayi.

Hal lain yang menyebabkan parsipasi IMD yang kurang yaitu responden tidakmelakukan kontak kulit dengan bayi selama 1jam, dikarenakan responden beranggapan bayi takut kedinginan dan ibukesakitan saat dijahit. Kontak kulit antara ibu danbayi selama 1 jam dapat menyesuaikan suhu ibudan bayi. Asumsi responden tersebut di dukungoleh Hidayat (2012) yaitu ibu yang baru sajamelahirkan terdapat peningkatan suhu dan bayiakan beradaptasi dengan suhu ibu. Dengandemikian resiko hypothermia dapat dihindari.

Lain halnya dengan edukasi yang diberikan oleh bidan, tingginya partisipatif kurang pada ibu disebabkan karena adanya responden yang tidak melakukan kontakvisual, tidak membelai bayi, dan ibu mendorongbayi menuju payudara dan ibu memberikanputingnya untuk menyusu. Hal 
tesebut karenapaparan informasi tentang tatalaksana IMD yangdidapat belum adekuat tentang tatalaksana IMD.Tatalaksana IMD jarang sekali dijelaskan olehpetugas kesehatan. Pemahaman respondententang tatalaksana IMD mempengaruhiperilakunya dalam bertindak. Partisipasimerupakan bagian dari sikap yang merupakankesediaan untuk bertindak (Notoatmodjo,2012).

\section{KESIMPULAN}

1. Umur, pendidikan, pekerjaan dan status gravid tidak mempengaruhi partisipasi ibu dalam melakukan IMD
2. Adanya pengaruh edukasi konselor laktasi terhadap partisipasi ibu melakukan IMD pada 1 jam setelah pasca persalinan

3. Edukasi laktasi yang diberikan konselor sebanyak $4 x$ saat prenatal secara berkesinambungan berpengaruh terhadap tingginya partisipasi ibu dalam melakukan IMD

\section{SARAN}

1. Konseling laktasi perlu juga diberikan pada orang tua dan suami

2. Perlu penelitian lebih lanjut dan dikembangkan secara lebih mendalam terutama variabel sosial budaya masyarakat, dukungan keluarga, serta pelatihan bidan terhadap pelaksanaan IMD

\section{DAFTAR PUSTAKA}

Azwar, A. 2003. Pelaksanaan Pemberian ASI Eksklusif di Indonesia, Masalah Pemberian ASI Kaitannya dengan Tumbuh Kembang Anak di Indonesia. Trans Info Media : Jakarta.

Bohari. 2011. Perubahan Pengetahuan, Sikap Ibu Hamil Setelah Edukasi di RSIA Siti Fatimah. Universitas Hasanuddin : Makassar.

Depkes. 2007. Pedoman Penyelenggaraan Pelatihan Konseling Menyusui dan Pelatihan Fasilitator Konseling Menyusui. Departemen Kesehatan : Jakarta

Febrianty, K. 2011. Perubahan Pengetahuan dan Sikap Ibu Hamil tentang Inisiasi Menyusu Dini Sebelum dan Sesudah Edukasi Di RSIA Pertiwi. Universitas Hasanuddin : Makassar.

Hastuti, TP. 2010. Faktor-Faktor yang Berhubungan dengan Pelaksanaan Program Inisiasi Menyusu Dini oleh Bidan Desa di Puskesmas Kabupaten Magelang. Universitas Diponegoro : Semarang.

Lowdermilk. Perry. Cashion. 2013. KeperawatanMaternitas. Singapura: Elsevier Mosby

Lumongga L, Namora. 2011. Memahami Dasar-Dasar Konseling Dalam Teori dan Praktik. Kencana Media Prenada Group : Jakarta.

Madjid. 2008. Asuhan Persalian Normal dan InisiasiMenyusu Dini. JHPIEGOCorporation : Jakarta.

Notoatmodjo, S. 2003. Pendidikan dan Perilaku Kesehatan. Rineka Cipta : Jakarta.

Notoatmodjo, S. 2007. Metodologi Penenlitian Kesehatan. Rineka Cipta : Jakarta

Notoatmodjo, S. 2010. Metodologi Penenlitian Kesehatan. Rineka Cipta : Jakarta.

Notoatmodjo, S. 2012. Promosi Kesehatan dan Perilaku Kesehatan. Rineka Cipta, Jakarta

Roesli U. 2008. Inisiasi Menyusu Dini Plus ASI Eksklusif (Cetakan I). Pustaka Bunda : Jakarta

Sukarni, Icesmi. 2013. Kehamilan, Persalinan, danNifas. Nuha Medika : Jakarta.

Tamara, Marina. 2011. Hubungan Inisiasi MenyusuDini dengan keberhasilan ASI Eksklusif danfaktor-faktor yang mempengaruhi. IndonesianJournal of Obstetrics and Gynecology.Vol.35

Virarisca S. 2010.Metode Persalinan dan Hubungannyadengan Inisiasi Menyusu Dini. Jurnal Gizi Klinik Indonesia . 2010; 7(2):92-8 